Review Article

\title{
The Role of the Dysfunctional Akt-Related Pathway in Cancer: Establishment and Maintenance of a Malignant Cell Phenotype, Resistance to Therapy, and Future Strategies for Drug Development
}

\author{
Gaetano Romano \\ Department of Biology, College of Science and Technology, Temple University, \\ Bio Life Science Building, Suite 456, 1900 N. 12th Street, Philadelphia, PA 19122, USA \\ Correspondence should be addressed to Gaetano Romano; gromano@temple.edu
}

Received 21 October 2013; Accepted 14 November 2013

Academic Editors: H. Hofler and K. Reiss

Copyright (c) 2013 Gaetano Romano. This is an open access article distributed under the Creative Commons Attribution License, which permits unrestricted use, distribution, and reproduction in any medium, provided the original work is properly cited.

\begin{abstract}
Akt serine/threonine kinases, or PKB, are key players in the regulation of a wide variety of cellular activities, such as growth, proliferation, protection from apoptotic injuries, control of DNA damage responses and genome stability, metabolism, migration, and angiogenesis. The Akt-related pathway responds to the stimulation mediated by growth factors, cytokines, hormones, and several nutrients. Akt is present in three isoforms: Akt1, Akt2, and Akt3, which may be alternatively named $\mathrm{PKB} \alpha, \mathrm{PKB} \beta$, and $\mathrm{PKB} \gamma$, respectively. The Akt isoforms are encoded on three diverse chromosomes and their biological functions are predominantly distinct. Deregulations in the Akt-related pathway were observed in many human maladies, including cancer, cardiopathies, neurological diseases, and type-2 diabetes. This review discusses the significance of the abnormal activities of the Akt axis in promoting and sustaining malignancies, along with the development of tumor cell populations that exhibit enhanced resistance to chemo- and/or radiotherapy. This occurrence may be responsible for the relapse of the disease, which is unfortunately very often related to fatal consequences in patients.
\end{abstract}

\section{Introduction}

Akt serine/threonine protein kinases are also termed $\mathrm{PKB}$ and constitute fundamental intracellular signaling systems for the regulation of an ample assortment of cellular and physiological activities, such as cell growth, proliferation, protection from apoptosis, modulation of DNA damage response and genome stability, motility, angiogenesis, and metabolism [1-7]. These Akt-mediated cellular functions are regulated by various types of external stimuli, which derive from the interaction of growth factors, hormones, cytokines, and nutrients with specific cellular receptors [1-7]. Some of the main hormones and growth factors that have the ability to stimulate the Akt axis comprise epidermal growth factor (EGF), insulin, insulin-like growth factor-I (IGF-I), vascular endothelial growth factor (VEGF), and nerve growth factor (NGF) [1-6]. Basically, the interaction between the external factors and the Akt axis occurs via ligand-cellular receptor binding, which, in turn, results in the transient Akt phosphorylation, with consequent temporary activation of the Akt intracellular signaling system. Overall, the Akt stimulation mediated by growth factors regulates cell cycle transition from G1/S to G2/M phase [1-7]. In addition, the Akt-related pathway comes into play in the orchestration of the DNA damage response and cellular genome stability [7]. Intracellular upstream effectors that activate the Akt-related pathway include phosphatidylinositol 3-kinase (PI3K) [8-10], LKB1 [11], and phosphatase and tensin homologue deleted on chromosome ten (PTEN) [12], whereas downstream regulators consist of mammalian target of rapamycin (mTOR) [13-15], eukaryotic initiation factor 4E (eIF4E) [16, 17], and tuberous sclerosis complex 2 (TSC2) [18-21]. Genetic analysis revealed that cellular protooncogenes encode Akt, eIF4E and the PI3K p85a regulatory subunit and p110 catalytic domain $[1-10,16$, 17]. Instead, tumor suppressor genes encode TSC2, PTEN, and LKB1 [11, 12, 18-21]. 


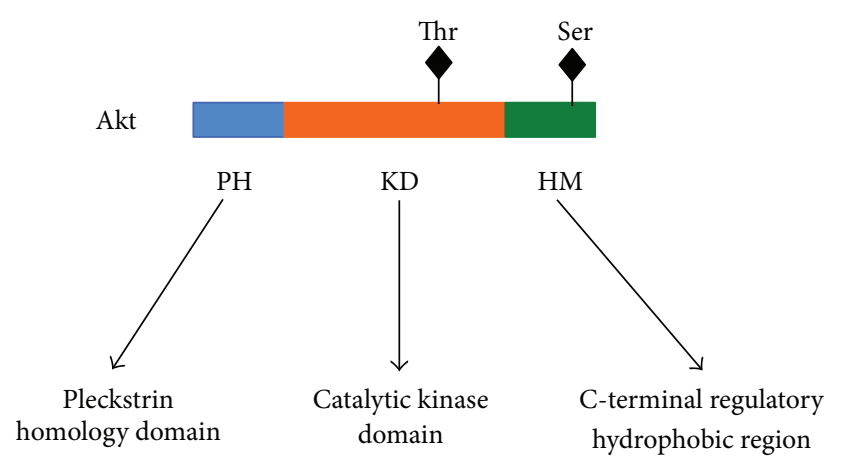

FIGURE 1: This figure illustrates the basic structure that is common among the three Akt isoforms (Akt1, Akt2, and Akt3). Each Akt isoform has three subdivisions: the Pleckstrin homology domain $(\mathrm{PH})$, the catalytic kinase domain, and the C-terminal regulatory hydrophobic region (HM). In addition, the Akt activating threonine (Thr) and serine (Ser) residues are indicated in the figure. The coordinates of these two amino acid residues vary slightly among the three Akt isoforms and are listed in Table 1. The phosphorylation of these threonine and serine residues induces the activation of the Akt signaling system.

The Akt protein kinase family is present in three isoforms: Akt1, Akt2, and Akt3, which are also termed $\operatorname{PKB} \alpha, \operatorname{PKB} \beta$, and $\mathrm{PKB} \gamma$, respectively [1-5]. The three Akt isoforms belong to the class of AGC kinases [1-5]. Moreover, they are encoded on three distinct chromosomes, share a considerable homology, and contain three common structures: the N-terminal pleckstrin homology domain $(\mathrm{PH})$, the catalytic kinase domain $(\mathrm{KD})$, and the C-terminal regulatory hydrophobic region (Figure 1) [1-5]. The catalytic and regulatory domains are both critical for the biological actions mediated by Akt protein kinases and exhibit the maximum degree of homology among the three Akt isoforms [22, 23]. The PH domain binds lipid substrates, such as phosphatidylinositol $(3,4)$ diphosphate (PIP2) and phosphatidylinositol $(3,4,5)$ triphosphate (PIP3). The ATP binding site is situated approximately in the middle of the catalytic kinase domain, which has a substantial degree of homology with the other components of the AGC kinases family, such as p70 S6 kinase (S6K) and p90 ribosomal S6 kinase (RSK), protein kinase A (PKA) and protein kinase $\mathrm{B}(\mathrm{PKB})$. The hydrophobic regulatory moiety is a typical feature of the AGC kinases family $[1-6,22,23]$. The concomitant phosphorylation of threonine and serine residues is essential to optimize the kinase activity of the three Akt isoforms [1-5]. These threonine and serine residues are positioned in marginally different locations in Aktl, Akt2, and Akt3 (Table 1). For instance, the most essential regulatory amino acid residues are threonine 308 and serine 473 in Akt1, whereas the amino acid residues are threonine 309 and serine 474 in Akt2. In the case of Akt3, the regulatory amino acid residues are threonine 305 and serine 472 [1-5].

Normally, Aktl and Akt 2 are ubiquitously present in every tissue, while Akt 3 expression is more circumscribed in terms of tissue distribution and exhibits a predominant expression in the central nervous system, heart, testis, kidneys, lungs, and skeletal muscles [24-26].
TABLE 1: Coordinates of the Akt activating threonine (Thr) and serine (Ser) residues among the three Akt isoforms.

\begin{tabular}{lcc}
\hline Akt isoform & $\begin{array}{c}\text { Position of Akt } \\
\text { activating Thr residue }\end{array}$ & $\begin{array}{c}\text { Position of Akt } \\
\text { activating Ser residue }\end{array}$ \\
\hline Akt1 & 308 & 473 \\
Akt2 & 309 & 474 \\
Akt3 & 305 & 472 \\
\hline
\end{tabular}

In recent years, a variety of studies conducted in Akt isoform-specific knockout mice unequivocally demonstrated that the biological functions of the three Akt isoforms are for the most part dissimilar from one another [2, 27-31]. For example, Aktl is essential for cell survival, as Aktl-null cells are more susceptible to apoptosis than Aktl-positive cells and Akt1 knockout mice are substantially smaller than wild-type littermates [32, 33]. Instead, Akt2 has a more prevalent role in the regulation of glucose homeostasis, as Akt2 knockout mice exhibit higher incidence of a type- 2 diabetes-like illness and primary cell cultures derived from these animals show evident ineffective glucose consumption [34, 35]. Akt3 has a more predominant purpose in postnatal brain development, as Akt3 knockout mice exhibit a median 25\% reduction in brain weight and size, even though no major anatomical deformities were reported in this study, besides a considerable decrease of white matter fiber connections in the corpus callosum [36]. Another report demonstrated that Akt2 has the ability to enhance the resistance of rod photoreceptor cells to apoptotic injuries that may be caused by light-related stress, whereas the other two Akt isoforms lack this property [28]. These findings were observed in knockout mice models, which also showed that light-induced cell stress specifically activates Akt2 [28]. Intriguingly, Akt1 is essential to enhance cell survival for the majority of cells, except for lightinduced cell stress in rod photoreceptor cells, which explicitly necessitate the activation of Akt2.

On these grounds, the three Akt isoforms exhibit differential biological characteristics and kinase activities, which are in function of the cellular context. In addition, a defective and less active Akt-related pathway does not provide an efficient protection from apoptotic injuries, which may become a contributing factor in the pathogenesis and/or clinical progression of several human maladies, such as neurodegenerative diseases [37-41], illnesses of the cardiovascular system [42$45]$, and type- 2 diabetes $[33,34,46]$. Conversely, the overexpression and/or constitutive enhanced activity of the Aktrelated pathway were observed in a wide variety of human tumors $[1,2,22,23,30,47-55]$. This paper discusses the implications of deregulations in the Akt signaling system that were reported in different types of cancer.

\section{Aberrant Akt-Related Pathways in Carcinogenesis and Progression of the Disease}

Carcinogenesis is a multistep process that depends on certain environmental factors and involves a series of genetic and epigenetic mutations, which, in turn, may result in the activation 
of cellular oncogenes and/or silencing of tumor suppressor genes [6, 56-72]. One of the hallmarks of the establishment and maintenance of a transformed cell phenotype is the overexpression and/or constitutive enhanced activity of the Aktrelated pathway, as clearly indicated by several lines of investigation [1-5, 73-77]. As already mentioned, the Akt intracellular signaling system is a main performer for the preservation of the overall control of cellular biology [1-6]. This control necessitates a steady equilibrium between the activities of cellular tumor suppressor factors and protooncogenes within the Akt pathway [1-18]. If for some reason the balance should fail, the role of the Akt axis-associated protooncogenes tends to prevail and, consequently, cause the constitutive enhanced activation and/or overexpression of Akt-related factors, which may contribute to the establishment and/or maintenance of a malignant cell phenotype $[1,2,22,23,30,47-$ 53, 73-77]. For example, a defective PTEN expression is very likely associated with an enhanced activity of the Akt axis, which is recurrently reported in many types of tumors [54, 61].

As anticipated, physiological levels of Akt activity take part in the regulation of DNA damage response and cellular genome stability [7]. However, constitutive enhanced levels of Akt activity may obstruct both ATR/Chk1 signaling and homologous recombination repair (HRR), either by direct phosphorylation of Chk1 and/or DNA topoisomerase 2binding protein 1 (TopBP1) or via prevention of assembly to the sites of DNA damage of double-strand break (DSB) resection factors, such as breast cancer susceptibility gene 1 (Brcal), replication protein A (RPA), and Rad51 [7, 78-80]. Thus, high levels of Akt activity may result in genome instability among malignant cells because of the loss of checkpoints and/or impairment of HRR functions [7].

The protooncogene TCL1 boosts the stimulation of the Akt axis activity through binding to the Akt $\mathrm{PH}$ domain [22]. Under normal physiological conditions, TCL1 expression is confined to cell populations of the immune system, during the early stages of development [22]. The increment of TCL1 expression levels in somatic cells is correlated with aberrant Akt kinase activity, as reported in different types of hematological malignancies and seminoma $[22,55]$. Moreover, TCL1 mediates Akt nuclear translocation [81]. The biological functions of nuclear Akt are currently under investigation [81, 82]. It has been proposed that the presence of Akt in the nucleus is instrumental in inhibiting apoptosis, by blocking the caspaseactivated deoxyribonuclease [83].

An early study showed that Akt2 overexpression transformed mouse fibroblast NIH/3T3 cells [84], whereas another report indicated that Akt2 overexpression increased substantially metastatic features and invasion both in human breast cancer and human ovarian cell lines [85]. Conversely, Akt1 and Akt3 overexpression failed to reproduce the effects that were observed for Akt2 overexpression in the previously mentioned human tumor cell lines [85]. This is a further evidence that accounts for the nonredundancy of the three Akt isoforms.

Some studies showed an involvement of aberrant PI3K/Akt3 activity in human melanoma [50, 86]. For instance, $70 \%$ of biopsies derived from patients with melanoma exhibited abnormal activities in the PI3K/Akt3-related signaling system [50]. A subsequent report showed that an enhanced PI3K/Akt3 pathway activity is one of the main contributors in the genesis of melanoma [86]. Moreover, several other studies supported the implication of the deregulated PI3K/Akt pathway in the development and/or clinical progression of melanoma [87-91].

Elevated Aktl expression levels were observed in human cancers of the gastric system [92], thyroid [23], and breast [93]. Similarly, estrogen receptor-negative breast cancer and androgen-independent prostate cancer lines exhibited a remarkable overexpression of Akt3 mRNA [94]. In this respect, several other reports showed the involvement of the hyperactive Akt signaling system in human tumors of the breast [67, 95-101] and prostate [61, 102-106]. Furthermore, increased levels of Akt2 expression were reported among the following human tumors: gliomas $[107,108]$, colorectal cancer [109], hepatocellular carcinoma [110], ovarian tumors [26], and pancreatic malignancies [111, 112].

In addition to enhanced levels of Akt expression, a number of Akt activating mutations were reported in various types of human cancers. For instance, a transforming point mutation that changes a single glutamic acid to lysine at amino acid residue $17(\mathrm{E} 17 \mathrm{~K})$ within the $\mathrm{PH}$ domain confers a continuous state of activation in Akt1 [113]. This somatic point mutation was identified in human breast, ovarian, and colorectal tumors [113]. Intriguingly, the E17K point mutation was absent in Akt2 and Akt 3 in the previously mentioned tumors [113], although an analogous point mutation in the Akt3 PH domain was found in human melanoma [114].

In most cases, point mutations that cause the constitutive activation of the Akt axis involve the genetic modification of the PI3K p110 catalytic subunit (PI3KCA) [115-123]. Such PI3KCA mutations were observed in a wide variety of human malignancies [121, 123]. Some of such human malignancies include cancers of the breast $[115,116,119]$, gastric system [117], colorectal tract [120], oral cavity [118], and thyroid [122].

A deregulated Akt activity is among the main factors that are implicated in the establishment of a malignant phenotype and/or progression of the clinical course of the disease [1$6,22,23,47-53]$. On these grounds, the Akt-related pathway may be considered a suitable target for cancer therapy [52, $55,57,79,124-126]$. However, the inhibition of the Akt axis is one of the requirements for enhanced cell motility [127-132]. In fact, the Akt signaling system suppresses the activity of the nuclear factor of activated T cells (NFAT) [127-131], which is a transcription factor that increases both cell motility and invasion in different kinds of malignancies [127-135]. Most likely, the Akt-induced inhibition of NFAT activity occurs through the Akt-mediated stimulation of the E3 ubiquitin-protein ligase Mdm2, which, in turn, promotes the degradation of NFAT [132]. Thus, the pharmacological inhibition of the Akt-related pathway in cancer therapy might unexpectedly become a contributing factor for the dissemination of cancer metastases [132]. Indeed, this is a very important aspect that should be taken under consideration in the planning of various therapeutic strategies for the treatment of malignancies in patients. 


\section{Abnormal Akt-Related Pathways in Resistance to Cancer Therapy}

Undoubtedly, the development of malignant cells with enhanced resistance to chemo- and/or radiotherapy is one of the most pressing issues for the field of oncology [62, 136146]. The onset of cancer cell variants with increased resistance to therapy may cause the relapse of the illness, which is often associated with fatal consequences in patients $[62,136-$ 146]. In this respect, an abundant number of reports persuasively confirmed that a deregulated Akt pathway is a key element for the generation of tumor cells with increased resistance to chemo- and/or radiotherapy [7, 136, 141, 143, 147$160]$. For instance, the Akt-related pathway is one of the main factors that may intervene in the development of increased resistance to cis-diamminedichloroplatinum (II) therapy $[141,158,159]$. The anticancer compound cis-diamminedichloroplatinum (II) is more commonly known either as cisplatin or CDDP $[141,158,159,161]$ and has been utilized for the treatment of several types of solid tumors, such as ovarian, testicular, head and neck, lung, colorectal, and bladder cancers [141, 160-164]. Cisplatin-mediated suppression of tumor growth occurs through various types of mechanisms [141]. The best-characterized and also predominant mechanism of cisplatin anticancer action consists of producing lesions within the cancer cell genome [141, 165-167], which are followed by the intervention of the DNA damage response system and mitochondrial apoptosis $[141,168,169]$. Specifically, the Akt-related pathway confers resistance to malignant cells against cisplatin treatment through a so-called off-target resistance mechanism, which may be induced by intracellular signaling systems that are not directly affected by cisplatin and come into play in the attempt to counterbalance the cisplatin-derived lethal effects in target cells (Figure 2) [141, $170,171]$. Generally, the Akt-mediated off-target resistance to cisplatin takes place in two stages. Initially, the PI3K/Akt signaling system is maintained at a baseline activity [141]. At this stage, there is an increase of cyclin-dependent kinase inhibitor 1A (CDKN1A) expression levels within the cell nucleus [171]. CDKN1A is also termed either $\mathrm{p} 21^{\mathrm{Cip} 1}$ or $\mathrm{p} 21^{\text {Waf1 }}$ [171]. During this period, the cisplatin-injured malignant cell may take advantage of a temporary CDKN1Ainduced cell cycle arrest to try to repair the damaged genomic DNA [141, 171]. In a second stage, however, survived malignant cells must resume the proliferation program [141]. This occurs through a subsequent increment of PI3K/Akt activity, which, in turn, is responsible for the nuclear rejection of CDKN1A [141, 171, 172]. Once CDKN1A is outside the cell nucleus, it can no longer impose a cell cycle arrest and, therefore, malignant cells recommence to proliferate [141]. A hyperactive PI3K/Akt signaling system is one of the contributing factors that are also responsible for the development of cancer cells with increased resistance to a broad spectrum of chemotherapeutics [136-194] and radiotherapy [143-150, 155-157]. Some of the anticancer drugs that become clinically ineffective comprise paclitaxel [171, 173-180], doxorubicin [180-182], gefitinib [152, 183-187], imatinib [186, 188-192], and flavopiridol [193, 194]. The clinical and/or preclinical studies on the Akt pathway-mediated enhanced resistance

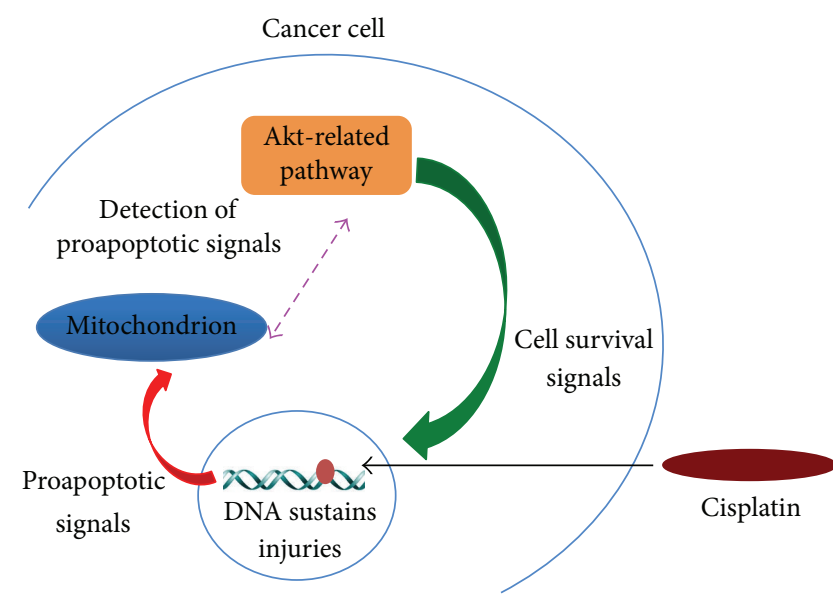

FIGURE 2: Basic off-target mechanism of Akt-induced malignant cell survival in response to cisplatin treatment.

to chemo- and/or radiotherapy were conducted on several types of human hematological tumors [195-198] and human epithelial malignancies [143, 147-160]. The latters included cancers of the brain, breast, ovaries, testicles, bladder, prostate, lung, colorectal tract, pancreas, and head and neck [143, 147-160].

In recent years, a number of PI3K/Akt/mTOR inhibitors have been developed for the treatment of different types of tumors [199-201]. Some PI3K/Akt/mTOR inhibitors comprise rapamycin, sirolimus, metformin, everolimus, and temsirolimus [199-201]. Although the PI3K/Akt/mTOR axis is a promising target for the treatment of cancer, randomized phase III clinical trials reported suboptimal beneficial therapeutic effects in patients [199-201]. Exceedingly high levels of toxicity were unfortunately observed in various clinical trials [199-201]. Moreover, the effects of the inhibition of the PI3K/Akt/mTOR pathway can be circumvented in cancer cells through the Raf/MEK/ERK signaling system [200], which may protect malignant cells from drug-induced proapoptotic injuries and, therefore, produce chemoresistant cancer cells variants [200].

In addition, the field of oncology is currently addressing the function of rare subpopulation of cancer cells with stem cell-like properties, or cancer stem cells, in the process of carcinogenesis, spreading of metastasis, regeneration of the tumor mass, and development of malignant cells with enhanced resistance to chemo and/or radiotherapy [152, 202211]. Such rare subpopulations of malignant cells with stem cell-like properties express the surface marker CD133 (or Prominin-1), which renders possible their identification in neoplastic tissues [202, 203, 212-221]. The efficient detection of CD133 expression in malignant tissues might assume a considerable prognostic importance [214]. According to the socalled cancer stem cell hypothesis, only specialized subsets of malignant cells with stem cell-like features have the ability to originate and maintain a malignancy [202-211]. Moreover, cancer stem cells are more resistant to toxic agents and radiations than other tumor cells [154, 202-211]. Therefore, anticancer therapeutics eliminate most of the malignant cells, 
but some cancer stem cells might be able to survive and, eventually, they reconstitute the tumor mass with cancer cell populations that are more resistant to chemo- and/or radiotherapy [154, 202-221]. Of course, the Akt-related pathway plays a strategic role also in the biology of cancer stem cells, as convincingly demonstrated by several reports [154, 210, 222226]. Indeed, the inhibition of the canonical Akt-related cell survival pathway constitutes a highly critical target for cancer therapy.

A study has recently shown that flavopiridol triggered a considerable Akt-Ser473 phosphorylation in human glioblastoma T98G cell line [194]. In contrast, as expected, flavopiridol treatment caused a reduction of Akt-Ser473 phosphorylation in human glioblastoma U87MG cell line and in human prostate cancer PC3 cell line [194]. As already discussed, Akt-Ser473 phosphorylation is a characteristic of the Aktrelated pathway activation, which, in turn, may protect cells from apoptotic injuries [1-5]. Flavopiridol is a pan-inhibitor of cyclin-dependent kinases and has been used in several clinical trials for the treatment of patients with various kinds of malignancies, albeit with modest therapeutic efficacy [57, 227-230]. The use of flavopiridol is supposed to impair the cellular signaling systems for protection from apoptosis and survival [57, 227-230]. However, the previously mentioned study on human glioblastoma T98G cell line indicates that flavopiridol might paradoxically play a relevant role in the production of tumor cell variants with enhanced resistance to chemotherapy, through increased activation of the Aktrelated pathway $[57,194]$. For this reason, various anticancer drugs should be screened to assess whether or not they may incidentally induce the increment of Akt-Ser473 phosphorylation in different types of human tumor cells [194].

Interestingly, it was also reported that a deregulated Akt axis has the ability to confer radioresistance to malignant cells by orchestrating DNA repair through nonhomologous end joining $(\mathrm{NHH})$ [7]. In this regard, a group of investigators observed a substantial $\gamma$-radiation-induced increment of Akt-Ser473 phosphorylation in a variety of human glioblastoma cell lines, such as U87MG, MO59J, and LN-18 [231].

Investigations are currently underway to determine the mechanisms of flavopiridol and/or $\gamma$-radiation-induced enhancement of Akt-Ser473 phosphorylation in human glioblastoma cell lines. In fact, a better understanding of these mechanisms may lead to the identification of novel therapeutic targets, which can be eventually suppressed with new drug formulations, in order to prevent the constitution of cancer cell variants that are more resilient to chemo- and/or radiotherapy.

\section{Conclusion}

Undeniably, a deregulated Akt pathway is an important factor in the establishment and/or maintenance of a malignant cell phenotype. Moreover, a constitutively activated Akt axis is involved in the generation of tumor cell variants with enhanced resistance to chemotherapeutic agents and/or radiotherapy.

On one hand, an abnormal Akt-related pathway is a very promising target to implement therapeutic approaches for the treatment of different types of cancer. On the other hand, the repression of the deregulated Akt signaling system, per se, does not seem to be sufficient for an effective therapy and may pose a number of collateral issues. For instance, a drug-induced inhibition of the Akt activity in malignant cells may unexpectedly contribute to the formation and/or dissemination of cancer metastases [127-132]. Another quite unforeseen side effect of the Akt pharmacological targeting is related to the flavopiridol-induced increment of Akt-Ser473 phosphorylation in human T98G glioblastoma cell line [194]. In addition, an increased Akt-Ser473 phosphorylation was observed following $\gamma$-irradiation of a panel of human glioblastoma cell lines [231]. All of these findings, taken together, suggest the pursuit of combinational therapeutic approaches for the treatment of different types of cancer [232-238], in order to prevent as much as possible treatmentrelated side effects that may paradoxically contribute to the spreading of metastases and/or to the generation of cancer cell variants with higher resistance to therapeutic interventions.

\section{Conflict of Interests}

The author declares that there is no conflict of interests regarding the publication of this paper.

\section{Acknowledgments}

This paper is dedicated to the loving memory of Silvio Santangelo. The author wishes to thank Drs. Jessica De Angelis and Claire Hamilton for their helpful comments on the paper.

\section{References}

[1] J. Downward, "PI 3-kinase, Akt and cell survival," Seminars in Cell and Developmental Biology, vol. 15, no. 2, pp. 177-182, 2004.

[2] E. Gonzalez and T. E. McGraw, "The Akt kinases: isoform specificity in metabolism and cancer," Cell Cycle, vol. 8, no. 16, pp. 2502-2508, 2009.

[3] J. Karar and A. Maity, "PI3K/AKT/mTOR pathway in angiogenesis," Frontiers in Molecular Neuroscience, vol. 4, article 51, 2011.

[4] J. M. Beaulieu, T. Del'Guidice, T. D. Sotnikova et al., "Beyond cAMP: the regulation of Akt and GSK3 by dopamine receptors," Frontiers in Molecular Neuroscience, vol. 4, article 38, 2011.

[5] S. M. Schultze, B. A. Hemmings, M. Niessen, and O. Tschopp, "PI3K/AKT, MAPK and AMPK signalling: protein kinases in glucose homeostasis," Expert Reviews in Molecular Medicine, vol. 14, article el, 2012.

[6] G. Romano, "The complex biology of the receptor for the insulin-like growth factor-1," Drug News and Perspectives, vol. 16, no. 8, pp. 525-531, 2003.

[7] N. Xu, Y. Lao, Y. Zhang, and D. A. Gillespie, "Akt: a doubleedged sword in cell proliferation and genome stability," Journal of Oncology, vol. 2012, Article ID 951724, 15 pages, 2012.

[8] L. Shayesteh, Y. Lu, W. L. Kuo et al., "PIK3CA is implicated as an oncogene in ovarian cancer," Nature Genetics, vol. 21, no. 1, pp. 99-102, 1999.

[9] A. J. Philp, I. G. Campbell, C. Leet et al., "The phosphatidylinositol $3^{\prime}$-kinase p85 $\alpha$ gene is an oncogene in human ovarian and 
colon tumors," Cancer Research, vol. 61, no. 20, pp. 7426-7429, 2001.

[10] K. E. Bachman, P. Argani, Y. Samuels et al., "The PIK3CA gene is mutated with high frequency in human breast cancers," Cancer Biology and Therapy, vol. 3, no. 8, pp. 772-775, 2004.

[11] J. Boudeau, G. Sapkota, and D. R. Alessi, "LKB1, a protein kinase regulating cell proliferation and polarity," FEBS Letters, vol. 546, no. 1, pp. 159-165, 2003.

[12] L. C. Cantley and B. G. Neel, "New insights into tumor suppression: PTEN suppresses tumor formation by restraining the phosphoinositide 3-kinase/AKT pathway," Proceedings of the National Academy of Sciences of the United States of America, vol. 96, no. 8, pp. 4240-4245, 1999.

[13] B. M. Slomovitz and R. L. Coleman, "The PI3K/AKT/mTOR pathway as a therapeutic target in endometrial cancer," Clinical Cancer Research, vol. 18, no. 21, pp. 5856-5864, 2012.

[14] S. M. Gaikwad and P. Ray, "Non-invasive imaging of PI3K/Akt/ mTOR signalling in cancer," American Journal of Nuclear Medicine and Molecular Imaging, vol. 2, no. 4, pp. 418-431, 2012.

[15] F. Zagouri, T. N. Sergentanis, D. Chrysikos et al., "mTOR inhibitors in breast cancer: a systematic review," Gynecologic Oncology, vol. 127, no. 3, pp. 662-672, 2012.

[16] H. G. Wendel, R. L. A. Silva, A. Malina et al., "Dissecting eIF4E action in tumorigenesis," Genes and Development, vol. 21, no. 24, pp. 3232-3237, 2007.

[17] S. Avdulov, S. Li, V. Michalek et al., "Activation of translation complex eIF4F is essential for the genesis and maintenance of the malignant phenotype in human mammary epithelial cells," Cancer Cell, vol. 5, no. 6, pp. 553-563, 2004.

[18] B. D. Manning and L. C. Cantley, "Rheb fills a GAP between TSC and TOR," Trends in Biochemical Sciences, vol. 28, no. 11, pp. 573-576, 2003.

[19] B. D. Manning, M. N. Logsdon, A. I. Lipovsky, D. Abbott, D. J. Kwiatkowski, and L. C. Cantley, "Feedback inhibition of Akt signaling limits the growth of tumors lacking Tsc2," Genes and Development, vol. 19, no. 15, pp. 1773-1778, 2005.

[20] D. J. Kwiatkowski, “Tuberous sclerosis: from tubers to mTOR," Annals of Human Genetics, vol. 67, no. 1, pp. 87-96, 2003.

[21] H. Onda, P. B. Crino, H. Zhang et al., “Tsc2 null murine neuroepithelial cells are a model for human tuber giant cells, and show activation of an mTOR pathway," Molecular and Cellular Neuroscience, vol. 21, no. 4, pp. 561-574, 2002.

[22] M. Noguchi, V. Ropars, C. Roumestand, and F. Suizu, "Protooncogene TCL1: more than just a coactivator for Akt," FASEB Journal, vol. 21, no. 10, pp. 2273-2284, 2007.

[23] A. Krześlak, L. Pomorski, and A. Lipińska, "Expression, localization, and phosphorylation of Aktl in benign and malignant thyroid lesions," Endocrine Pathology, vol. 22, no. 4, pp. 206-211, 2011.

[24] P. F. Jones, T. Jakubowicz, F. J. Pitossi, F. Maurer, and B. A. Hemmings, "Molecular cloning and identification of a serine/threonine protein kinase of the second-messenger subfamily," Proceedings of the National Academy of Sciences of the United States of America, vol. 88, no. 10, pp. 4171-4175, 1991.

[25] D. Brodbeck, P. Cron, and B. A. Hemmings, "A human protein kinase $\mathrm{B} \gamma$ with regulatory phosphorylation sites in the activation loop and in the C-terminal hydrophobic domain," Journal of Biological Chemistry, vol. 274, no. 14, pp. 9133-9136, 1999.

[26] J. Q. C. Jin Quan Cheng, A. K. Godwin, A. Bellacosa et al., "AKT2, a putative oncogene encoding a member of a subfamily of protein-serine/threonine kinases, is amplified in human ovarian carcinomas," Proceedings of the National Academy of Sciences of the United States of America, vol. 89, no. 19, pp. 92679271, 1992.

[27] R. S. Lee, C. M. House, B. E. Cristiano et al., "Relative expression levels rather than specific activity plays the major role in determining in vivo AKT isoform substrate specificity," Enzyme Research, vol. 2011, Article ID 720985, 18 pages, 2011.

[28] G. Li, R. E. Anderson, H. Tomita et al., "Nonredundant role of Akt2 for neuroprotection of rod photoreceptor cells from lightinduced cell death," Journal of Neuroscience, vol. 27, no. 1, pp. 203-211, 2007.

[29] B. Dummler, O. Tschopp, D. Hynx, Z. Z. Yang, S. Dirnhofer, and B. A. Hemmings, "Life with a single isoform of Akt: mice lacking Akt2 and Akt3 are viable but display impaired glucose homeostasis and growth deficiencies," Molecular and Cellular Biology, vol. 26, no. 21, pp. 8042-8051, 2006.

[30] L. Heron-Milhavet, N. Khouya, A. Fernandez, and N. J. Lamb, "Aktl and Akt2: differentiating the aktion," Histology and Histopathology, vol. 26, no. 5, pp. 651-662, 2011.

[31] S. M. Schultze, J. Jensen, B. A. Hemmings, O. Tschopp, and M. Niessen, "Promiscuous affairs of PKB/AKT isoforms in metabolism," Archives of Physiology and Biochemistry, vol. 117, no. 2, pp. 70-77, 2011.

[32] W. S. Chen, P. Z. Xu, K. Gottlob et al., "Growth retardation and increased apoptosis in mice with homozygous disruption of the akt1 gene," Genes and Development, vol. 15, no. 17, pp. 22032208, 2001.

[33] H. Cho, J. L. Thorvaldsen, Q. Chu, F. Feng, and M. J. Birnbaum, "Akt1/PKB $\alpha$ is required for normal growth but dispensable for maintenance of glucose homeostasis in mice," Journal of Biological Chemistry, vol. 276, no. 42, pp. 38349-38352, 2001.

[34] R. S. Garofalo, S. J. Orena, K. Rafidi et al., "Severe diabetes, agedependent loss of adipose tissue, and mild growth deficiency in mice lacking Akt2/PKB $\beta$," Journal of Clinical Investigation, vol. 112, no. 2, pp. 197-208, 2003.

[35] O. Tschopp, Z. Z. Yang, D. Brodbeck et al., "Essential role of protein kinase $\mathrm{B} \gamma(\mathrm{PKB} \gamma / \mathrm{Akt} 3)$ in postnatal brain developmental but not in glucose homeostasis," Development, vol. 132, no. 13, pp. 2943-2954, 2005.

[36] G. Vilahur, O. Juan-Babot, E. Peña, B. Oñate, L. Casaní, and L. Badimon, "Molecular and cellular mechanisms involved in cardiac remodeling after acute myocardial infarction," Journal of Molecular and Cellular Cardiology, vol. 50, no. 3, pp. 522-533, 2011.

[37] L. Heimfarth, S. O. Loureiro, M. F. Dutra et al., "In vivo treatment with diphenyl ditelluride induces neurodegeneration in striatum of young rats: implications of MAPK and Akt pathways," Toxicology and Applied Pharmacology, vol. 264, no. 2, pp. 143-152, 2012.

[38] C. O’Neill, A. P. Kiely, M. F. Coakley et al., "Insulin and IGF1 signalling: longevity, protein homoeostasis and Alzheimer's disease," Biochemical Society Transactions, vol. 40, no. 4, pp. 721727, 2012.

[39] M. Castro-Caldas, A. N. Carvalho, E. Rodrigues et al., "Tauroursodeoxycholic acid prevents MPTP-induced dopaminergic cell death in a mouse model of Parkinson's disease," Molecular Neurobiology, vol. 46, no. 2, pp. 475-486, 2012.

[40] S. R. Kim, V. Ries, H. C. Cheng et al., "Age and $\alpha$-synuclein expression interact to reveal a dependence of dopaminergic axons on endogenous Akt/PKB signaling," Neurobiology of Disease, vol. 44, no. 2, pp. 215-222, 2011. 
[41] S. Jimenez, M. Torres, M. Vizuete et al., "Age-dependent accumulation of soluble amyloid $\beta(\mathrm{A} \beta)$ oligomers reverses the neuroprotective effect of soluble amyloid precursor protein$\alpha(\mathrm{sAPP} \alpha)$ by modulating phosphatidylinositol 3-kinase (PI3K)/Akt-GSK-3 $\beta$ pathway in Alzheimer mouse model," Journal of Biological Chemistry, vol. 286, no. 21, pp. 18414-18425, 2011.

[42] A. Schorlemmer, M. L. Matter, and R. V. Shohet, "Cardioprotective Signaling by Endothelin," Trends in Cardiovascular Medicine, vol. 18, no. 7, pp. 233-239, 2008.

[43] P. Fischer and D. Hilfiker-Kleiner, "Survival pathways in hypertrophy and heart failure: the gp130-STAT3 axis," Basic Research in Cardiology, vol. 102, no. 5, pp. 393-411, 2007.

[44] C. Skurk, Y. Izumiya, H. Maatz et al., “The FOXO3a transcription factor regulates cardiac myocyte size downstream of AKT signaling," Journal of Biological Chemistry, vol. 280, no. 21, pp. 20814-20823, 2005.

[45] S. Guo, A. T. Som, C. Waeber, and E. H. Lo, "Vascular neuroprotection via TrkB- and Akt-dependent cell survival signaling," Journal of Neurochemistry, vol. 123, supplement 2, pp. 58-64, 2012.

[46] A. Stears, S. O'Rahilly, R. K. Semple, and D. B. Savage, "Metabolic insights from extreme human insulin resistance phenotypes," Best Practice and Research, vol. 26, no. 2, pp. 145-157, 2012.

[47] J. R. Testa and P. N. Tsichlis, "AKT signaling in normal and malignant cells," Oncogene, vol. 24, no. 50, pp. 7391-7393, 2005.

[48] D. A. Altomare and J. R. Testa, "Perturbations of the AKT signaling pathway in human cancer," Oncogene, vol. 24, no. 50, pp. 7455-7464, 2005.

[49] R. M. Memmott and P. A. Dennis, "Akt-dependent and -independent mechanisms of mTOR regulation in cancer," Cellular Signalling, vol. 21, no. 5, pp. 656-664, 2009.

[50] S. V. Madhunapantula, P. J. Mosca, and G. P. Robertson, “The Akt signaling pathway: an emerging therapeutic target in malignant melanoma," Cancer Biology and Therapy, vol. 12, no. 12, pp. 1032-1049, 2011.

[51] L. Million and S. S. Donaldson, "Resectable pediatric nonrhabdomyosarcoma soft tissue sarcoma: which patients benefit from adjuvant radiation therapy and how much?" ISRN Oncologyogy, vol. 2012, Article ID 341408, 6 pages, 2012.

[52] K. Almhanna, J. Strosberg, and M. Malafa, "Targeting AKT protein kinase in gastric cancer," Anticancer Research, vol. 31, no. 12, pp. 4387-4392, 2011.

[53] I. M. Bennani-Baiti, "Epigenetic and epigenomic mechanisms shape sarcoma and other mesenchymal tumor pathogenesis," Epigenomics, vol. 3, no. 6, pp. 715-732, 2011.

[54] E. Tokunaga, E. Oki, A. Egashira et al., "Deregulation of the akt pathway in human cancer," Current Cancer Drug Targets, vol. 8, no. 1, pp. 27-36, 2008.

[55] M. A. Teitell, "The TCL1 family of oncoproteins: co-activators of transformation," Nature Reviews Cancer, vol. 5, no. 8, pp. 640648, 2005.

[56] G. Romano, "Development of safer gene delivery systems to minimize the risk of insertional mutagenesis-related malignancies: a critical issue for the field of gene therapy," ISRN Oncologyogy, vol. 2012, Article ID 616310, 14 pages, 2012.

[57] G. Romano, "Deregulations in the cyclin-dependent kinase-9related pathway in cancer: implications for drug discovery and development," ISRN Oncologyogy, vol. 2013, Article ID 305371, 14 pages, 2013.
[58] D. D. Gan, M. Macaluso, C. Cinti, K. Khalili, and A. Giordano, "How does a normal human cell become a cancer cell?" Journal of Experimental and Clinical Cancer Research, vol. 22, no. 4, pp. 509-516, 2003.

[59] C. Caterina, M. Marcella, and A. Giordano, "Tumor-specific exon 1 mutations could be the 'hit event' predisposing Rb2/p130 gene to epigenetic silencing in lung cancer," Oncogene, vol. 24, no. 38, pp. 5821-5826, 2005.

[60] M. Macaluso, M. Montanari, C. Cinti, and A. Giordano, "Modulation of cell cycle components by epigenetic and genetic events," Seminars in Oncology, vol. 32, no. 5, pp. 452-457, 2005.

[61] K. Reiss, J. Y. Wang, G. Romano et al., "IGF-I receptor signaling in a prostatic cancer cell line with a PTEN mutation," Oncogene, vol. 19, no. 22, pp. 2687-2694, 2000.

[62] A. Giordano, A. Fucito, G. Romano, and I. R. Marino, "Carcinogenesis and environment: the cancer stem cell hypothesis and implications for the development of novel therapeutics and diagnostics," Frontiers in Bioscience, vol. 12, no. 9, pp. 3475-3482, 2007.

[63] R. Visone and C. M. Croce, "MiRNAs and cancer," American Journal of Pathology, vol. 174, no. 4, pp. 1131-1138, 2009.

[64] M. M. Streppel, S. Pai, N. R. Campbell et al., "MicroRNA 223 is upregulated in the multistep progression of Barrett's esophagus and modulates sensitivity to chemotherapy by targeting PARP1," Clinical Cancer Research, vol. 19, no. 15, pp. 4067-4078, 2013.

[65] A. K. Alitalo, S. T. Proulx, S. Karaman et al., "VEGF-C and VEGF-D blockade inhibits inflammatory skin carcinogenesis," Cancer Research, vol. 73, no. 14, pp. 4212-4221, 2013.

[66] H. Shiraha, K. Yamamoto, and M. Namba, "Human hepatocyte carcinogenesis (review)," International Journal of Oncology, vol. 42, no. 4, pp. 1133-1138, 2013.

[67] E. Rinninella, M. A. Zocco, A. de Gaetano et al., "From small nodule to overt HCC: a multistep process of carcinogenesis as seen during surveillance," European Review For Medical and Pharmacological Sciences, vol. 16, no. 9, pp. 1292-1294, 2012.

[68] B. W. Futscher, "Epigenetic changes during cell transformation," Advances in Experimental Medicine and Biology, vol. 754, pp. 179-194, 2013.

[69] F. Y. Al-Marzoqee, G. Khoder, H. Al-Awadhi et al., "Upregulation and inhibition of the nuclear translocation of Oct4 during multistep gastric carcinogenesis," International Journal of Oncology, vol. 41, no. 5, pp. 1733-1743, 2012.

[70] J. H. Rüschoff, T. Brandenburger, E. E. Strehler et al., "Plasma membrane calcium ATPase expression in human colon multistep carcinogenesis," Cancer Investigation, vol. 30, no. 4, pp. 251257, 2012.

[71] M. Demaria, S. Misale, C. Giorgi et al., "STAT3 can serve as a hit in the process of malignant transformation of primary cells," Cell Death and Differentiation, vol. 19, no. 8, pp. 1390-1397, 2012.

[72] C. H. Siar, M. C. Mah, and P. P. Gill, "Prevalence of bilateral 'mirror-image' lesions in patients with oral potentially malignant epithelial lesions," European Archives of Oto-RhinoLaryngology, vol. 269, no. 3, pp. 999-1004, 2012.

[73] R. L. Carpenter and B. H. Jiang, "Roles of EGFR, PI3K, AKT, and mTOR in heavy metal-induced cancer," Current Cancer Drug Target, vol. 13, no. 3, pp. 252-266, 2013.

[74] Z. C. Dobbin and C. N. Landen, "The importance of the $\mathrm{PI} 3 \mathrm{~K} / \mathrm{AKT} / \mathrm{MTOR}$ pathway in the progression of ovarian cancer," International Journal of Molecular Sciences, vol. 14, no. 4, pp. 8213-8227, 2013. 
[75] E. Agarwal, M. G. Brattain, and S. Chowdhury, "Cell survival and metastasis regulation by Akt signaling in colorectal cancer," Cell Signal, vol. 25, no. 8, pp. 1711-1719, 2013.

[76] A. K. Goulioumis, J. Varakis, P. Goumas, and H. Papadaki, "Androgen receptor in laryngeal carcinoma: could there be an androgen-refractory tumor?" ISRN Oncology, vol. 2011, Article ID 180518, 5 pages, 2011.

[77] D. Tamkus, A. Sikorskii, K. A. Gallo et al., "Endothelin-1 enriched tumor phenotype predicts breast cancer recurrence," ISRN Oncology, vol. 2013, Article ID 385398, 7 pages, 2013.

[78] H. Chen, M. Lisby, and L. S. Symington, "RPA coordinates DNA end resection and prevents formation of DNA hairpins," Molecular Cell, vol. 50, no. 4, pp. 589-600, 2013.

[79] S. Vidal-Eychenié, C. Décaillet, J. Basbous, and A. Constantinou, "DNA structure-specific priming of ATR activation by DNA-PKcs," The Journal of Cell Biology, vol. 202, no. 3, pp. 421942, 2013.

[80] N. M. Shanbhag and R. A. Greenberg, "The dynamics of DNA damage repair and transcription," Methods in Molecular Biology, vol. 1042, pp. 227-235, 2013.

[81] Y. Pekarsky, A. Koval, C. Hallas et al., "Tcl1 enhances Akt kinase activity and mediates its nuclear translocation," Proceedings of the National Academy of Sciences of the United States of America, vol. 97, no. 7, pp. 3028-3033, 2000.

[82] N. N. Ahmed, T. F. Franke, A. Bellacosa et al., "The proteins encoded by c-akt and v-akt differ in post-translational modification, subcellular localization and oncogenic potential," Oncogene, vol. 8, no. 7, pp. 1957-1963, 1993.

[83] A. M. Martelli, G. Tabellini, D. Bressanin et al., "The emerging multiple roles of nuclear Akt," Biochimica et Biophysica Acta, vol. 1823, no. 12, pp. 2168-2178, 2012.

[84] J. Q. Cheng, D. A. Altomare, M. A. Klein et al., "Transforming activity and mitosis-related expression of the AKT2 oncogene: evidence suggesting a link between cell cycle regulation and oncogenesis," Oncogene, vol. 14, no. 23, pp. 2793-2801, 1997.

[85] M. J. Arboleda, J. F. Lyons, F. F. Kabbinavar et al., "Overexpression of AKT2/protein kinase $\mathrm{B} \beta$ leads to up-regulation of $\beta 1$ integrins, increased invasion, and metastasis of human breast and ovarian cancer cells," Cancer Research, vol. 63, no. 1, pp. 196206, 2003.

[86] J. M. Stahl, A. Sharma, M. Cheung et al., "Deregulated Akt3 activity promotes development of malignant melanoma," Cancer Research, vol. 64, no. 19, pp. 7002-7010, 2004.

[87] M. A. Davies, "The role of the PI3K-AKT pathway in melanoma," Cancer Journal, vol. 18, no. 2, pp. 142-147, 2012.

[88] A. Conde-Perez and L. Larue, "PTEN and melanomagenesis," Future Oncology, vol. 8, no. 9, pp. 1109-1120, 2012.

[89] M. F. Segura, H. S. Greenwald, D. Hanniford et al., "MicroRNA and cutaneous melanoma: from discovery to prognosis and therapy," Carcinogenesis, vol. 33, no. 10, pp. 1823-1832, 2012.

[90] A. R. Jazirehi, P. B. Wenn, and M. Damavand, "Therapeutic implications of targeting the PI3Kinase/AKT/mTOR signaling module in melanoma therapy," American Journal of Cancer Research, vol. 2, no. 2, pp. 178-191, 2012.

[91] K. S. M. Smalley, "Understanding melanoma signaling networks as the basis for molecular targeted therapy," Journal of Investigative Dermatology, vol. 130, no. 1, pp. 28-37, 2010.

[92] S. P. Staal, "Molecular cloning of the akt oncogene and its human homologues AKT1 and AKT2: amplification of AKT1 in a primary human gastric adenocarcinoma," Proceedings of the National Academy of Sciences of the United States of America, vol. 84, no. 14, pp. 5034-5037, 1987.
[93] O. Stål, G. Pérez-Tenorio, L. Akerberg et al., "Akt kinases in breast cancer and the results of adjuvant therapy," Breast Cancer Research, vol. 5, no. 2, pp. R37-R44, 2003.

[94] K. Nakatani, D. A. Thompson, A. Barthel et al., "Up-regulation of Akt3 in estrogen receptor-deficient breast cancers and androgen-independent prostate cancer lines," Journal of Biological Chemistry, vol. 274, no. 31, pp. 21528-21532, 1999.

[95] L. W. Bowers, D. A. Cavazos, A. J. Brenner et al., "Obesity enhances nongenomic estrogen receptor crosstalk with the PI3K/Akt and MAPK pathways to promote in vitro measures of breast cancer progression," Breast Cancer Research, vol. 5, no. 4, article R59, 2013.

[96] E. M. Fox, M. G. Kuba, T. W. Miller et al., "Autocrine IGFI/Insulin receptor axis compensates for inhibition of AKT in ER-positive breast cancer cells with acquired resistance to estrogen deprivation," Breast Cancer Research, vol. 15, no. 4, article R55, 2013.

[97] R. Saxena, V. Chandra, M. Manohar et al., "Chemotherapeutic potential of 2-[piperidinoethoxyphenyl]-3-phenyl-2Hbenzo(b)pyran in estrogen receptor-negative breast cancer cells: action via prevention of EGFR activation and combined inhibition of PI-3-K/Akt/FOXO and MEK/Erk/AP-1 pathways," PLoS One, vol. 8, no. 6, Article ID e66246, 2013.

[98] A. Fucito, C. Lucchetti, A. Giordano, and G. Romano, "Genetic and epigenetic alterations in breast cancer: what are the perspectives for clinical practice?" International Journal of Biochemistry and Cell Biology, vol. 40, no. 4, pp. 565-575, 2008.

[99] J. M. Renoir, V. Marsaud, and G. Lazennec, "Estrogen receptor signaling as a target for novel breast cancer therapeutics," Biochemical Pharmacology, vol. 85, no. 4, pp. 449-465, 2013.

[100] J. Cidado and B. H. Park, "Targeting the PI3K/Akt/mTOR pathway for breast cancer therapy," Journal of Mammary Gland Biology and Neoplasia, vol. 17, no. 3-4, pp. 205-216, 2012.

[101] E. S. Lianidou, A. Markou, and A. Strati, "Molecular characterization of circulating tumor cells in breast cancer: challenges and promises for individualized cancer treatment," Cancer and Metastasis Reviews, vol. 31, no. 3-4, pp. 663-671, 2012.

[102] T. Ribarska, K. M. Bastian, A. Koch, and W. A. Schulz, "Specific changes in the expression of imprinted genes in prostate cancer-implications for cancer progression and epigenetic regulation," Asian Journal of Andrology, vol. 14, no. 3, pp. 436-450, 2012.

[103] B. Wegiel, S. Evans, R. Hellsten, L. E. Otterbein, A. Bjartel, and J. L. Persson, "Molecular pathways in the progression of hormone-independent and metastatic prostate cancer," Current Cancer Drug Targets, vol. 10, no. 4, pp. 392-401, 2010.

[104] D. Sarker, A. H. M. Reid, T. A. Yap, and J. S. de Bono, “Targeting the PI3K/AKT pathway for the treatment of prostate cancer," Clinical Cancer Research, vol. 15, no. 15, pp. 4799-4805, 2009.

[105] P. L. de Souza, P. J. Russell, and J. Kearsley, "Role of the akt pathway in prostate cancer," Current Cancer Drug Targets, vol. 9, no. 2, pp. 163-175, 2009.

[106] A. Shukla-Dave, H. Hricak, N. M. Ishill et al., "Correlation of MR imaging and MR spectroscopic imaging findings with Ki67, phospho-Akt, and androgen receptor expression in prostate cancer," Radiology, vol. 250, no. 3, pp. 803-812, 2009.

[107] Y. Wang, X. Wang, J. Zhang et al., "MicroRNAs involved in the EGFR/PTEN/AKT pathway in gliomas," Journal of NeuroOncology, vol. 106, no. 2, pp. 217-224, 2012. 
[108] J. Zhang, L. Han, A. Zhang et al., "AKT2 expression is associated with glioma malignant progression and required for cell survival and invasion," Oncology Reports, vol. 24, no. 1, pp. 65-72, 2010.

[109] H. K. Roy, B. F. Olusola, D. L. Clemens et al., "AKT protooncogene overexpression is an early event during sporadic colon carcinogenesis," Carcinogenesis, vol. 23, no. 1, pp. 201-205, 2002.

[110] X. Xu, M. Sakon, H. Nagano et al., "Akt2 expression correlates with prognosis of human hepatocellular carcinoma," Oncology Reports, vol. 11, no. 1, pp. 25-32, 2004.

[111] J. Q. Cheng, B. Ruggeri, W. M. Klein et al., "Amplification of AKT2 in human pancreatic cancer cells and inhibition of AKT2 expression and tumorigenicity by antisense RNA," Proceedings of the National Academy of Sciences of the United States of America, vol. 93, no. 8, pp. 3636-3641, 1996.

[112] B. A. Ruggeri, L. Huang, M. Wood et al., "Amplification and overexpression of the AKT2 oncogene in a subset of human pancreatic ductal adenocarcinomas," Molecular Carcinogenesis, vol. 21, no. 2, pp. 81-86, 1998.

[113] J. D. Carpten, A. L. Faber, C. Horn et al., "A transforming mutation in the pleckstrin homology domain of AKT1 in cancer," Nature, vol. 448, no. 7152, pp. 439-444, 2007.

[114] M. A. Davies, K. Stemke-Hale, C. Tellez et al., "A novel AKT3 mutation in melanoma tumours and cell lines," British Journal of Cancer, vol. 99, no. 8, pp. 1265-1268, 2008.

[115] H. A. Dbouk, B. D. Khalil, H. Wu et al., "Characterization of a tumor-associated activating mutation of the p110 $\beta$ PI 3-kinase," PLoS One, vol. 8, no. 5, Article ID e63833, 2013.

[116] E. L. Kehr, J. M. Jorns, D. Ang et al., "Mucinous breast carcinomas lack PIK3CA and AKT1 mutations," Human Pathology, vol. 43, no. 12, pp. 2207-2212, 2012.

[117] Y. Sukawa, H. Yamamoto, K. Nosho et al., "Alterations in the human epidermal growth factor receptor 2-phosphatidylinositol 3-kinase-v-Akt pathway in gastric cancer," World Journal of Gastroenterology, vol. 18, no. 45, pp. 6577-6656, 2012.

[118] A. K. Murugan, A. K. Munirajan, and N. Tsuchida, "Genetic deregulation of the PIK3CA oncogene in oral cancer," Cancer Letters, vol. 338, no. 2, pp. 193-203, 2013.

[119] T. W. Miller, B. N. Rexer, J. T. Garrett, and C. L. Arteaga, "Mutations in the phosphatidylinositol 3-kinase pathway: role in tumor progression and therapeutic implications in breast cancer," Breast Cancer Research, vol. 13, no. 6, article 224, 2011.

[120] X. Liao, T. Morikawa, P. Lochhead et al., "Prognostic role of PIK3CA mutation in colorectal cancer: cohort study and literature review," Clinical Cancer Research, vol. 18, no. 8, pp. 22572268, 2012.

[121] P. K. Vogt, J. R. Hart, M. Gymnopoulos et al., "Phosphatidylinositol 3-kinase: the oncoprotein," Current topics in microbiology and immunology, vol. 347, pp. 79-104, 2010.

[122] M. Xing, "Genetic alterations in the phosphatidylinositol-3 kinase/Akt pathway in thyroid cancer," Thyroid, vol. 20, no. 7, pp. 697-706, 2010.

[123] Y. Samuels and T. Waldman, "Oncogenic mutations of PIK3CA in human cancers," Current Topics in Microbiology and Immunology, vol. 347, pp. 21-41, 2010.

[124] S. Patel, "Exploring novel therapeutic targets in GIST: focus on the PI3K/Akt/mTOR pathway," Current Oncology Reports, vol. 15, no. 4, pp. 386-395, 2013.
[125] K. S. Saini, S. Loi, E. de Azambuja et al., "Targeting the $\mathrm{PI} 3 \mathrm{~K} / \mathrm{AKT} / \mathrm{mTOR}$ and Raf/MEK/ERK pathways in the treatment of breast cancer," Cancer Treatment Reviews, vol. 39, no. 8, pp. 935-946, 2013.

[126] V. Castel, V. Segura, and P. Berlanga, "Emerging drugs for neuroblastoma," Expert Opinion on Emerging Drugs, vol. 18, no. 2, pp. 155-171, 2013.

[127] M. Yoeli-Lerner, G. K. Yiu, I. Rabinovitz, P. Erhardt, S. Jauliac, and A. Toker, "Akt blocks breast cancer cell motility and invasion through the transcription factor NFAT," Molecular Cell, vol. 20, no. 4, pp. 539-550, 2005.

[128] H. Y. Irie, R. V. Pearline, D. Grueneberg et al., "Distinct roles of Akt1 and Akt2 in regulating cell migration and epithelialmesenchymal transition," Journal of Cell Biology, vol. 171, no. 6, pp. 1023-1034, 2005.

[129] A. Toker and M. Yoeli-Lerner, "Akt signaling and cancer: surviving but not moving on," Cancer Research, vol. 66, no. 8, pp. 3963-3966, 2006.

[130] M. Yoeli-Lerner and A. Toker, "Akt/PKB signaling in cancer: a function in cell motility and invasion," Cell Cycle, vol. 5, no. 6, pp. 603-605, 2006.

[131] V. Stambolic and J. R. Woodgett, "Functional distinctions of protein kinase B/Akt isoforms defined by their influence on cell migration," Trends in Cell Biology, vol. 16, no. 9, pp. 461-466, 2006.

[132] S. L. Wyszomierski and D. Yu, "A knotty turnabout? Aktl as a metastasis suppressor," Cancer Cell, vol. 8, no. 6, pp. 437-439, 2005.

[133] G. K. Yiu, A. Kaunisto, Y. R. Chin, and A. Toker, "NFAT promotes carcinoma invasive migration through glypican-6," Biochemical Journal, vol. 440, no. 1, pp. 157-166, 2011.

[134] M. B. F. Werneck, A. Vieira-De-Abreu, R. Chammas, and J. P. B. Viola, "NFAT1 transcription factor is central in the regulation of tissue microenvironment for tumor metastasis," Cancer Immunology, Immunotherapy, vol. 60, no. 4, pp. 537-546, 2011.

[135] G. K. Yiu and A. Toker, "NFAT induces breast cancer cell invasion by promoting the induction of cyclooxygenase-2," Journal of Biological Chemistry, vol. 281, no. 18, pp. 12210-12217, 2006.

[136] M. M. Gottesman, "Mechanisms of cancer drug resistance," Annual Review of Medicine, vol. 53, pp. 615-627, 2002.

[137] V. Merino, N. V. Jiménez-Torres, and M. Merino-Sanjuán, “Relevance of multidrug resistance proteins on the clinical efficacy of cancer therapy," Current Drug Delivery, vol. 1, no. 3, pp. 203212, 2004.

[138] R. Pérez-Tomás, "Multidrug resistance: retrospect and prospects in anti-cancer drug treatment," Current Medicinal Chemistry, vol. 13, no. 16, pp. 1859-1876, 2006.

[139] B. Tan, D. Piwnica-Worms, and L. Ratner, "Multidrug resistance transporters and modulation," Current Opinion in Oncology, vol. 12, no. 5, pp. 450-458, 2000.

[140] J. D. O'Flaherty, M. Barr, D. Fennell et al., “The cancer stem cell hypothesis: its emerging role in lung cancer biology and its relevance for future therapy," Journal of Thoracic Oncology, vol. 7, no. 12, pp. 1880-1890, 2012.

[141] L. Galluzzi, L. Senovilla, I. Vitale et al., "Molecular mechanisms of cisplatin resistance," Oncogene, vol. 31, no. 15, pp. 1869-1883, 2012.

[142] T. W. Meijer, J. H. Kaanders, P. N. Span, and J. Bussink, “Targeting hypoxia, HIF-1, and tumor glucose metabolism to improve radiotherapy efficacy," Clinical Cancer Research, vol. 18, no. 20, pp. 5585-5594, 2012. 
[143] R. S. Narayan, C. A. Fedrigo, L. J. Stalpers et al., "Targeting the Akt-pathway to improve radiosensitivity in glioblastoma," Current Pharmaceutical Design, vol. 19, no. 5, pp. 951-957, 2013.

[144] C. Moncharmont, A. Levy, M. Gilormini et al., "Targeting a cornerstone of radiation resistance: cancer stem cell," Cancer Letters, vol. 322, no. 2, pp. 139-147, 2012.

[145] C. Patel, L. Stenke, S. Varma et al., "Multidrug resistance in relapsed acute myeloid leukemia: evidence of biological heterogeneity," Cancer, vol. 119, no. 16, pp. 3076-3083, 2013.

[146] J. Rodon, R. Dienstmann, V. Serra, and J. Tabernero, "Development of PI3K inhibitors: lessons learned from early clinical trials," Nature Reviews Clinical Oncology, vol. 10, no. 3, pp. 143-153, 2013.

[147] M. Toulany, K. Dittmann, M. Krüger, M. Baumann, and H. P. Rodemann, "Radioresistance of K-Ras mutated human tumor cells is mediated through EGFR-dependent activation of PI3KAKT pathway," Radiotherapy and Oncology, vol. 76, no. 2, pp. 143-150, 2005.

[148] M. Minjgee, M. Toulany, R. Kehlbach, K. Giehl, and H. P. Rodemann, "K-RAS(V12) induces autocrine production of EGFR ligands and mediates radioresistance through EGFR-dependent Akt signaling and activation of DNA-PKcs," International Journal of Radiation Oncology Biology Physics, vol. 81, no. 5, pp. 1506-1514, 2011.

[149] T. Shimura, "Acquired radioresistance of cancer and the AKT/GSK3 $\beta /$ cyclin D1 overexpression cycle," Journal of Radiation Research, vol. 52, no. 5, pp. 539-544, 2011.

[150] A. Affolter, M. Drigotas, K. Fruth et al., "Increased radioresistance via G12S K-Ras by compensatory upregulation of MAPK and PI3K pathways in epithelial cancer," Head and Neck, vol. 35, no. 2, pp. 220-228, 2013.

[151] Q. Chen, W. Li, Y. Wan et al., "Amplified in breast cancer 1 oncogene enhances human cholangiocarcinoma growth and chemoresistance by simultaneous activation of Akt and Nrf2 pathways," Hepatology, vol. 55, no. 6, pp. 1820-1829, 2012.

[152] S. Maseki, K. Ijichi, H. Tanaka et al., "Acquisition of EMT phenotype in the gefitinib-resistant cells of a head and neck squamous cell carcinoma cell line through Akt/GSK-3B/snail signalling pathway," British Journal of Cancer, vol. 106, no. 6, pp. 1196-1204, 2012.

[153] S. M. Gadgeel and A. Wozniak, "Preclinical rationale for PI3K/Akt/mTOR pathway inhibitors as therapy for epidermal growth factor receptor inhibitor-resistant non-small-cell lung cancer," Clinical Lung Cancer, vol. 14, no. 4, pp. 322-332, 2013.

[154] H. Sartelet, T. Imbriglio, C. Nyalendo et al., "CD133 expression is associated with poor outcome in neuroblastoma via chemoresistance mediated by the AKT pathway," Histopathology, vol. 60, no. 7, pp. 1144-1155, 2012.

[155] L. A. Fernandez, M. Squatrito, P. Northcott et al., "Oncogenic YAP promotes radioresistance and genomic instability in medulloblastoma through IGF2-mediated Akt activation," Oncogene, vol. 31, no. 15, pp. 1923-1937, 2012.

[156] C. A. Fedrigo, I. Grivicich, D. P. Schunemann et al., "Radioresistance of human glioma spheroids and expression of HSP70, p53 and EGFr," Radiation Oncology, vol. 6, no. 1, article 156, 2011.

[157] S. F. Isebaert, J. V. Swinnen, W. H. McBride, and K. M. Haustermans, "Insulin-like growth factor-type 1 receptor inhibitor NVP-AEW541 enhances radiosensitivity of PTEN wild-type but not PTEN-deficient human prostate cancer cells," International Journal of Radiation Oncology Biology Physics, vol. 81, no. 1, pp. 239-247, 2011.
[158] D. S. Tan, R. E. Miller, and S. B. Kaye, "New perspectives on molecular targeted therapy in ovarian clear cell carcinoma," British Journal of Cancer, vol. 108, no. 8, pp. 1553-1559, 2013.

[159] E. A. Stronach, M. Chen, E. N. Maginn et al., "DNA-PK mediates AKT activation and apoptosis inhibition in clinically acquired platinum resistance," Neoplasia, vol. 13, no. 11, pp. 1069-1080, 2011.

[160] T. Yin, H. Wei, Z. Leng et al., "Bmi-1 promotes the chemoresistance, invasion and tumorigenesis of pancreatic cancer cells," Chemotherapy, vol. 57, no. 6, pp. 488-496, 2012.

[161] J. Fijołek, E. Wiatr, E. Rowińska-Zakrzewska et al., "p53 and HER2/neu expression in relation to chemotherapy response in patients with non-small cell lung cancer," International Journal of Biological Markers, vol. 21, no. 2, pp. 81-87, 2006.

[162] A. W. Prestayko, J. C. D’Aoust, B. F. Issell, and S. T. Crooke, "Cisplatin (cis-diamminedichloroplatinum II)," Cancer Treatment Reviews, vol. 6, no. 1, pp. 17-39, 1979.

[163] D. Lebwohl and R. Canetta, "Clinical development of platinum complexes in cancer therapy: an historical perspective and an update," European Journal of Cancer, vol. 34, no. 10, pp. 15221534, 1998.

[164] M. Galanski, "Recent developments in the field of anticancer platinum complexes," Recent Patents on Anti-Cancer Drug Discovery, vol. 1, no. 2, pp. 285-295, 2006.

[165] T. Furuta, T. Ueda, G. Aune, A. Sarasin, K. H. Kraemer, and Y. Pommier, "Transcription-coupled nucleotide excision repair as a determinant of cisplatin sensitivity of human cells," Cancer Research, vol. 62, no. 17, pp. 4899-4902, 2002.

[166] T. A. Kunkel and D. A. Erie, "DNA mismatch repair," Annual Review of Biochemistry, vol. 74, pp. 681-710, 2005.

[167] I. Vitale, L. Galluzzi, M. Castedo, and G. Kroemer, "Mitotic catastrophe: a mechanism for avoiding genomic instability," Nature Reviews, vol. 12, no. 6, pp. 385-392, 2011.

[168] L. Galluzzi, E. Morselli, O. Kepp, I. Vitale, M. Pinti, and G. Kroemer, "Mitochondrial liaisons of p53," Antioxidants and Redox Signaling, vol. 15, no. 6, pp. 1691-1714, 2011.

[169] G. Kroemer, L. Galluzzi, and C. Brenner, "Mitochondrial membrane permeabilization in cell death," Physiological Reviews, vol. 87, no. 1, pp. 99-163, 2007.

[170] A. Citri and Y. Yarden, "EGF-ERBB signalling: towards the systems level," Nature Reviews Molecular Cell Biology, vol. 7, no. 7, pp. 505-516, 2006.

[171] Y. Mitsuuchi, S. W. Johnson, M. Selvakumaran, S. J. Williams, T. C. Hamilton, and J. R. Testa, "The phosphatidylinositol 3kinase/AKT signal transduction pathway plays a critical role in the expression of $\mathrm{p} 21$ (WAF1/CIP1/SDI1) induced by cisplatin and paclitaxel," Cancer Research, vol. 60, no. 19, pp. 5390-5394, 2000.

[172] M. Ikeguchi and N. Kaibara, "Changes in survivin messenger RNA level during cisplatin treatment in gastric cancer," International Journal of Molecular Medicine, vol. 8, no. 6, pp. 661-666, 2001.

[173] G. Levallet, E. Bergot, M. Antoine et al., "High TUBB3 expression, an independent prognostic marker in patients with early non-small cell lung cancer treated by preoperative chemotherapy, is regulated by K-Ras signaling pathway," Molecular Cancer Therapeutics, vol. 11, no. 5, pp. 1203-1213, 2012.

[174] W. Zhang, W. Ding, Y. Chen et al., "Up-regulation of breast cancer resistance protein plays a role in HER2-mediated chemoresistance through PI3K/Akt and nuclear factor-kappa B signaling pathways in MCF7 breast cancer cells," Acta Biochimica et Biophysica Sinica, vol. 43, no. 8, pp. 647-653, 2011. 
[175] M. K. S. Tang, H. Y. Zhou, J. W. P. Yam, and A. S. T. Wong, "c-Met overexpression contributes to the acquired apoptotic resistance of nonadherent ovarian cancer cells through a cross talk mediated by phosphatidylinositol 3-kinase and extracellular signalregulated kinase 1/2," Neoplasia, vol. 12, no. 2, pp. 128-138, 2010.

[176] S. Merighi, A. Benini, P. Mirandola et al., "Hypoxia inhibits paclitaxel-induced apoptosis through adenosine-mediated phosphorylation of bad in glioblastoma cells," Molecular Pharmacology, vol. 72, no. 1, pp. 162-172, 2007.

[177] Y. Wang, Y. Qu, X. L. Niu, W. J. Sun, X. L. Zhang, and L. Z. $\mathrm{Li}$, "Autocrine production of interleukin-8 confers cisplatin and paclitaxel resistance in ovarian cancer cells," Cytokine, vol. 56, no. 2, pp. 365-375, 2011.

[178] Z. Y. Fu, J. H. Lv, C. Y. Ma, D. P. Yang, and T. Wang, “Tissue inhibitor of metalloproteinase-1 decreased chemosensitivity of MDA-435 breast cancer cells to chemotherapeutic drugs through the PI3K/AKT/NF-kcyrillicB pathway," Biomedicine and Pharmacotherapy, vol. 65, no. 3, pp. 163-167, 2011.

[179] S. H. Kim, Y. S. Juhnn, and Y. S. Song, "Akt involvement in paclitaxel chemoresistance of human ovarian cancer cells," Annals of the New York Academy of Sciences, vol. 1095, pp. 82-89, 2007.

[180] V. Gagnon, C. van Themsche, S. Turner, V. Leblanc, and E. Asselin, "Akt and XIAP regulate the sensitivity of human uterine cancer cells to cisplatin, doxorubicin and taxol," Apoptosis, vol. 13, no. 2, pp. 259-271, 2008.

[181] S. A. Maxwell and S. Mousavi-Fard, "Non-Hodgkin's B-cell lymphoma: advances in molecular strategies targeting drug resistance," Experimental Biology and Medicine, vol. 238, no. 9, pp. 971-990, 2013.

[182] J. G. van Oosterwijk, M. A. van Ruler, I. H. Briaire-de Bruijn et al., "Src kinases in chondrosarcoma chemoresistance and migration: dasatinib sensitises to doxorubicin in TP53 mutant cells," British Journal of Cancer, vol. 109, no. 5, pp. 1214-1222, 2013.

[183] B. N. Liu, H. Q. Yan, X. Wu et al., "Apoptosis induced by benzyl isothiocyanate in gefitinib-resistant lung cancer cells is associated with Akt/MAPK pathways and generation of reactive oxygen species," Cell Biochemistry and Biophysics, vol. 66, no. 1, pp. 81-92, 2013.

[184] H. Li, S. Zhou, X. Li et al., "Gefitinib-resistance is related to BIM expression in non-small cell lung cancer cell lines," Cancer Biotherapy and Radiopharmaceuticals, vol. 28, no. 2, pp. 115-123, 2013.

[185] Y. S. Wang, Y. H. Wang, H. P. Xia et al., "MicroRNA-214 regulates the acquired resistance to gefitinib via the PTEN/AKT pathway in EGFR-mutant cell lines," Asian Pacific Journal of Cancer Prevention, vol. 13, no. 1, pp. 255-260, 2012.

[186] A. Pick and M. Wiese, "Tyrosine kinase inhibitors influence ABCG2 expression in EGFR-positive MDCK BCRP cells via the PI3K/Akt signaling pathway," ChemMedChem, vol. 7, no. 4, pp. 650-662, 2012.

[187] A. S. Bodzin, Z. Wei, R. Hurtt, T. Gu, and C. Doria, "Gefitinib resistance in HCC mahlavu cells: upregulation of CD133 expression, activation of IGF-1R signaling pathway, and enhancement of IGF-1R nuclear translocation," Journal of Cellular Physiology, vol. 227, no. 7, pp. 2947-2952, 2012.

[188] S. Isoyama, S. Dan, Y. Nishimura et al., "Establishment of phosphatidylinositol 3-kinase inhibitor-resistant cancer cell lines and therapeutic strategies for overcoming the resistance," Cancer Science, vol. 103, no. 11, pp. 1955-1960, 2012.
[189] F. U. Wöhrle, S. Halbach, K. Aumann et al., "Gab2 signaling in chronic myeloid leukemia cells confers resistance to multiple Bcr-Abl inhibitors," Leukemia, vol. 27, no. 1, pp. 118-129, 2013.

[190] A. Puissant, M. Dufies, N. Fenouille et al., "Imatinib triggers mesenchymal-like conversion of CML cells associated with increased aggressiveness," Journal of Molecular Cell Biology, vol. 4, no. 4, pp. 207-220, 2012.

[191] E. J. Kim and M. M. Zalupski, "Systemic therapy for advanced gastrointestinal stromal tumors: beyond imatinib," Journal of Surgical Oncology, vol. 104, no. 8, pp. 901-906, 2011.

[192] J. M. Brandwein, D. W. Hedley, S. Chow et al., "A phase I/II study of imatinib plus reinduction therapy for c-kit-positive relapsed/refractory acute myeloid leukemia: inhibition of Akt activation correlates with complete response," Leukemia, vol. 25, no. 6, pp. 945-952, 2011.

[193] L. A. Gomez, A. de las Pozas, and C. Perez-Stable, "Sequential combination of flavopiridol and docetaxel reduces the levels of $\mathrm{X}$-linked inhibitor of apoptosis and AKT proteins and stimulates apoptosis in human LNCaP prostate cancer cells," Molecular Cancer Therapeutics, vol. 5, no. 5, pp. 1216-1226, 2006.

[194] V. Caracciolo, G. Laurenti, G. Romano et al., "Flavopiridol induces phosphorylation of AKT in a human glioblastoma cell line, in contrast to siRNA-mediated silencing of Cdk9: implications for drug design and development," Cell Cycle, vol. 11, no. 6, pp. 1202-1216, 2012.

[195] O. Frolova, I. Samudio, J. M. Benito et al., "Regulation of HIF-1 $\alpha$ signaling and chemoresistance in acute lymphocytic leukemia under hypoxic conditions of the bone marrow microenvironment," Cancer Biology \& Therapy, vol. 13, no. 10, pp. 858-870, 2012.

[196] S. W. Hofbauer, J. D. Piñón, G. Brachtl et al., "Modifying Akt signaling in B-cell chronic lymphocytic leukemia cells," Cancer Research, vol. 70, no. 18, pp. 7336-7344, 2010.

[197] V. L. Grandage, R. E. Gale, D. C. Lich, and A. Khwaja, "PI3kinase/Akt is constitutively active in primary acute myeloid leukaemia cells and regulates survival and chemoresistance via NF- $\kappa$ B, MAPkinase and p53 pathways," Leukemia, vol. 19, no. 4, pp. 586-594, 2005.

[198] E. Rao, C. Jiang, M. Ji et al., "The miRNA-17 92 cluster mediates chemoresistance and enhances tumor growth in mantle cell lymphoma via PI3K/AKT pathway activation," Leukemia, vol. 26, no. 5, pp. 1064-1072, 2012.

[199] A. K. Greenberg, J. C. Tsay, K. M. Tchou-Wong et al., "Chemoprevention of lung cancer: prospects and disappointments in human clinical trials," Cancers, vol. 5, no. 1, pp. 131-148, 2013.

[200] K. S. Saini, S. Loi, E. de Azambuja et al., "Targeting the $\mathrm{PI} 3 \mathrm{~K} / \mathrm{AKT} / \mathrm{mTOR}$ and Raf/MEK/ERK pathways in the treatment of breast cancer," Cancer Treatment Reviews, vol. 39, no. 8, pp. 935-946, 2013.

[201] T. K. Owonikoko and F. R. Khuri, "Targeting the PI3K/AKT/ mTOR pathway," in American Society of Clinical Oncology Educational Book, pp. 395-401, 2013.

[202] D. Mizrak, M. Brittan, and M. R. Alison, "CD 133: molecule of the moment," Journal of Pathology, vol. 214, no. 1, pp. 3-9, 2008.

[203] J. Neuzil, M. Stantic, R. Zobalova et al., "Tumour-initiating cells vs. cancer 'stem' cells and CD133: what's in the name?" Biochemical and Biophysical Research Communications, vol. 355, no. 4, pp. 855-859, 2007.

[204] R. Zobalova, M. Stantic, K. Prokopova, L. F. Dong, and J. Neuzil, "Cancer cells with high expression of CD133 exert FLIP upregulation and resistance to TRAIL-induced apoptosis," BioFactors, vol. 34, no. 3, pp. 231-235, 2009. 
[205] T. Reya, S. J. Morrison, M. F. Clarke, and I. L. Weissman, "Stem cells, cancer, and cancer stem cells," Nature, vol. 414, no. 6859, pp. 105-111, 2001.

[206] B. T. Tan, C. Y. Park, L. E. Ailles, and I. L. Weissman, “The cancer stem cell hypothesis: a work in progress," Laboratory Investigation, vol. 86, no. 12, pp. 1203-1207, 2006.

[207] S. K. Singh, C. Hawkins, I. D. Clarke et al., "Identification of human brain tumour initiating cells," Nature, vol. 432, no. 7015, pp. 396-401, 2004.

[208] S. K. Singh, I. D. Clarke, T. Hide, and P. B. Dirks, "Cancer stem cells in nervous system tumors," Oncogene, vol. 23, no. 43, pp. 7267-7273, 2004.

[209] S. K. Singh, I. D. Clarke, M. Terasaki et al., "Identification of a cancer stem cell in human brain tumors," Cancer Research, vol. 63, no. 18, pp. 5821-5828, 2003.

[210] H. Sartelet, T. Imbriglio, C. Nyalendo et al., "CD133 expression is associated with poor outcome in neuroblastoma via chemoresistance mediated by the AKT pathway," Histopathology, vol. 60, no. 7, pp. 1144-1155, 2012.

[211] B. Annabi, S. Rojas-Sutterlin, C. Laflamme et al., "Tumor environment dictates medulloblastoma cancer stem cell expression and invasive phenotype," Molecular Cancer Research, vol. 6, no. 6, pp. 907-916, 2008.

[212] F. Ren, W. Q. Sheng, and X. Du, "CD133: a cancer stem cells marker, is used in colorectal cancers," World Journal of Gastroenterology, vol. 19, no. 17, pp. 2603-2611, 2013.

[213] R. V. Lloyd, H. Hardin, and C. Montemayor-Garcia, "Stem cells and cancer stem-like cells in endocrine tissues," Endocrine Pathology, vol. 24, no. 1, pp. 1-10, 2013.

[214] R. H. Dahlrot, S. K. Hermansen, S. Hansen, and B. W. Kristensen, "What is the clinical value of cancer stem cell markers in gliomas?" International Journal of Clinical and Experimental Pathology, vol. 6, no. 3, pp. 334-348, 2013.

[215] J. D. O’Flaherty, M. Barr, D. Fennell et al., "The cancer stemcell hypothesis: its emerging role in lung cancer biology and its relevance for future therapy," Journal of Thoracic Oncology, vol. 7, no. 12, pp. 1880-1890, 2012.

[216] Z. Yu, T. G. Pestell, M. P. Lisanti, and R. G. Pestell, "Cancer stem cells," The International Journal of Biochemistry \& Cell Biology, vol. 44, no. 12, pp. 2144-2151, 2012.

[217] T. Kokuryo, Y. Yokoyama, and M. Nagino, "Recent advances in cancer stem cell research for cholangiocarcinoma," Journal of Hepato-Biliary-Pancreatic Surgery, vol. 19, no. 6, pp. 606-613, 2012.

[218] P. Grosse-Gehling, C. A. Fargeas, C. Dittfeld et al., "CD133 as a biomarker for putative cancer stem cells in solid tumours: limitations, problems and challenges," The Journal of Pathology, vol. 229, no. 3, pp. 355-378, 2013.

[219] R. W. Pang and R. T. Poon, "Cancer stem cell as a potential therapeutic target in hepatocellular carcinoma," Current Cancer Drug Targets, vol. 12, no. 9, pp. 1081-1094, 2012.

[220] J. Ji and X. W. Wang, "Clinical implications of cancer stem cell biology in hepatocellular carcinoma," Seminars in Oncology, vol. 39, no. 4, pp. 461-472, 2012.

[221] S. R. Bohl, A. Pircher, and W. Hilbe, "Cancer stem cells: characteristics and their potential role for new therapeutic strategies," Onkologie, vol. 34, no. 5, pp. 269-274, 2011.

[222] P. Dandawate, S. Padhye, A. Ahmad, and F. H. Sarkar, "Novel strategies targeting cancer stem cells through phytochemicals and their analogs," Drug Delivery and Translational Research, vol. 3, no. 2, pp. 165-182, 2013.
[223] X. Luo, Z. Dong, Y. Chen et al., "Enrichment of ovarian cancer stem-like cells is associated with epithelial to mesenchymal transition through an miRNA-activated AKT pathway," Cell Proliferation, vol. 46, no. 4, pp. 436-446, 2013.

[224] K. He, T. Xu Y, Xu et al., "Cancer cells acquire a drug resistant, highly tumorigenic, cancer stem-like phenotype through modulation of the PI3K/Akt/ $\beta$-catenin/CBP pathway," International Journal of Cancer, vol. 134, no. 1, pp. 43-54, 2014.

[225] A. Sinclair, A. L. Latif, and T. L. Holyoake, "Targeting survival pathways in chronic myeloid leukaemia stem cells," British Journal of Pharmacology, vol. 169, no. 8, pp. 1693-1707, 2013.

[226] D. Hambardzumyan, M. Squatrito, E. Carbajal, and E. C. Holland, "Glioma formation, cancer stem cells, and Akt signaling," Stem Cell Reviews, vol. 4, no. 3, pp. 203-210, 2008.

[227] M. Malumbres, P. Pevarello, M. Barbacid, and J. R. Bischoff, "CDK inhibitors in cancer therapy: what is next?" Trends in Pharmacological Sciences, vol. 29, no. 1, pp. 16-21, 2008.

[228] H. Weinmann and R. Metternich, "Drug discovery process for kinase inhibitors," ChemBioChem, vol. 6, no. 3, pp. 455-459, 2005.

[229] M. Malumbres and M. Barbacid, "Mammalian cyclin-dependent kinases," Trends in Biochemical Sciences, vol. 30, no. 11, pp. 630-641, 2005.

[230] M. Malumbres and M. Barbacid, "Cell cycle kinases in cancer," Current Opinion in Genetics and Development, vol. 17, no. 1, pp. 60-65, 2007.

[231] H. F. Li, J. S. Kim, and T. Waldman, "Radiation-induced Akt activation modulates radioresistance in human glioblastoma cells," Radiation Oncology, vol. 4, article 43, 2009.

[232] K. Sheppard, K. M. Kinross, B. Solomon et al., "Targeting PI3 kinase/AKT/mTOR signaling in cancer," Critical Reviews in Oncogenesis, vol. 17, no. 1, pp. 69-95, 2012.

[233] P. Zhou, S. W. Cheng, R. Yang, B. Wang, and J. Liu, “Combination chemoprevention: future direction of colorectal cancer prevention," European Journal of Cancer Prevention, vol. 21, no. 3, pp. 231-240, 2012.

[234] Y. Y. Zaytseva, J. D. Valentino, P. Gulhati, and B. Mark Evers, "MTOR inhibitors in cancer therapy," Cancer Letters, vol. 319, no. 1, pp. 1-7, 2012.

[235] S. Shi, W. Yao, J. Xu, J. Long, C. Liu, and X. Yu, "Combinational therapy: new hope for pancreatic cancer?" Cancer Letters, vol. 317, no. 2, pp. 127-135, 2012.

[236] N. Emami-shahri and T. Hagemann, "Resistance-the true face of biological defiance," Rheumatology, vol. 51, no. 3, pp. 413-422, 2012.

[237] M. Torabi-Rahvar, M. Bozorgmehr, M. Jeddi-Tehrani, and A. H. Zarnani, "Potentiation strategies of dendritic cell-based antitumor vaccines: combinational therapy takes the front seat," Drug Discovery Today, vol. 16, no. 15-16, pp. 733-740, 2011.

[238] G. Ghavami, M. R. Kazemali, and S. Sardari, "Informatics of drug synergism in naturally occurring anticancer agents," Recent Patents on Anti-Cancer Drug Discovery, vol. 6, no. 1, pp. 26-44, 2011. 


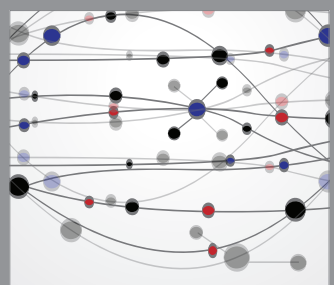

The Scientific World Journal
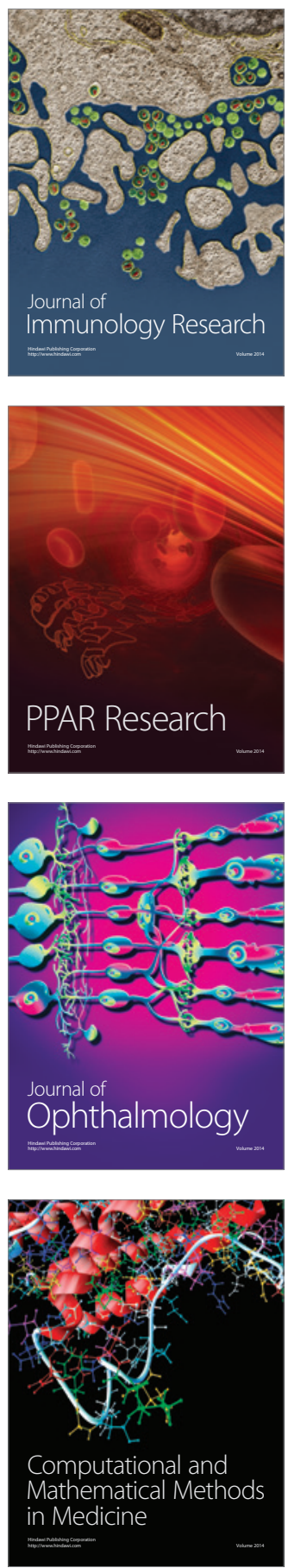

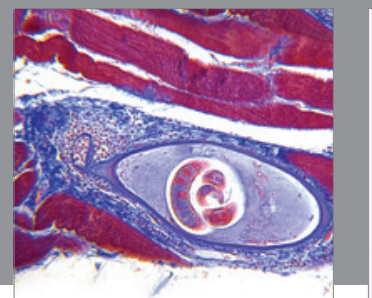

Gastroenterology

Research and Practice
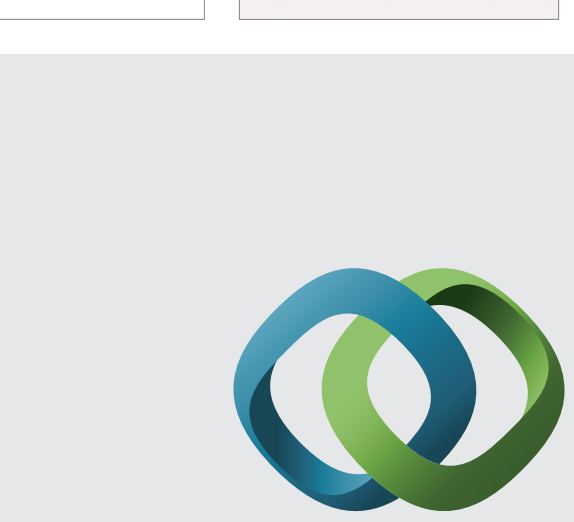

\section{Hindawi}

Submit your manuscripts at

http://www.hindawi.com
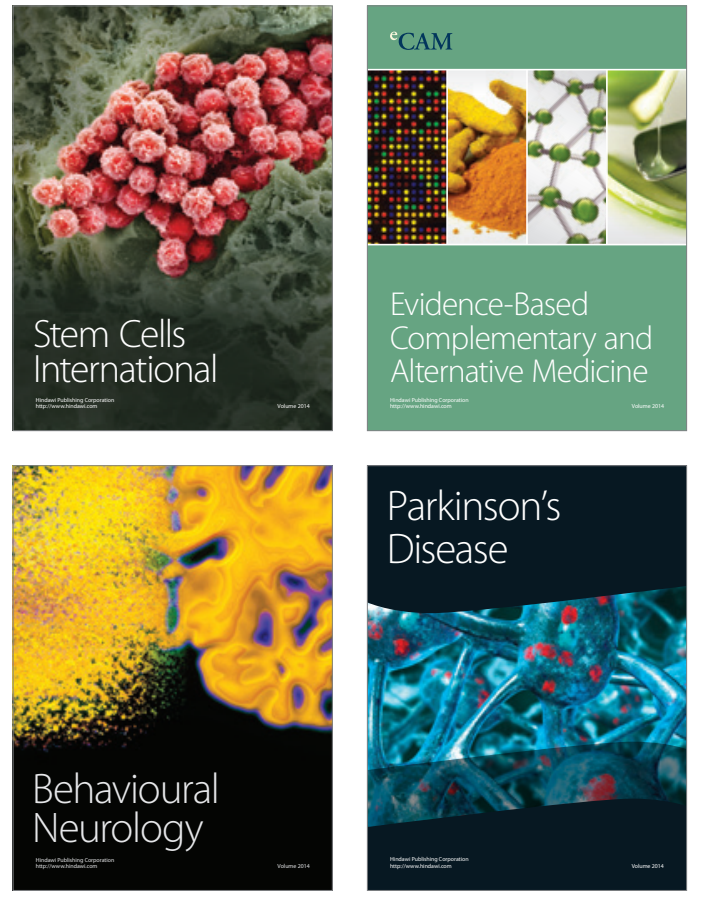
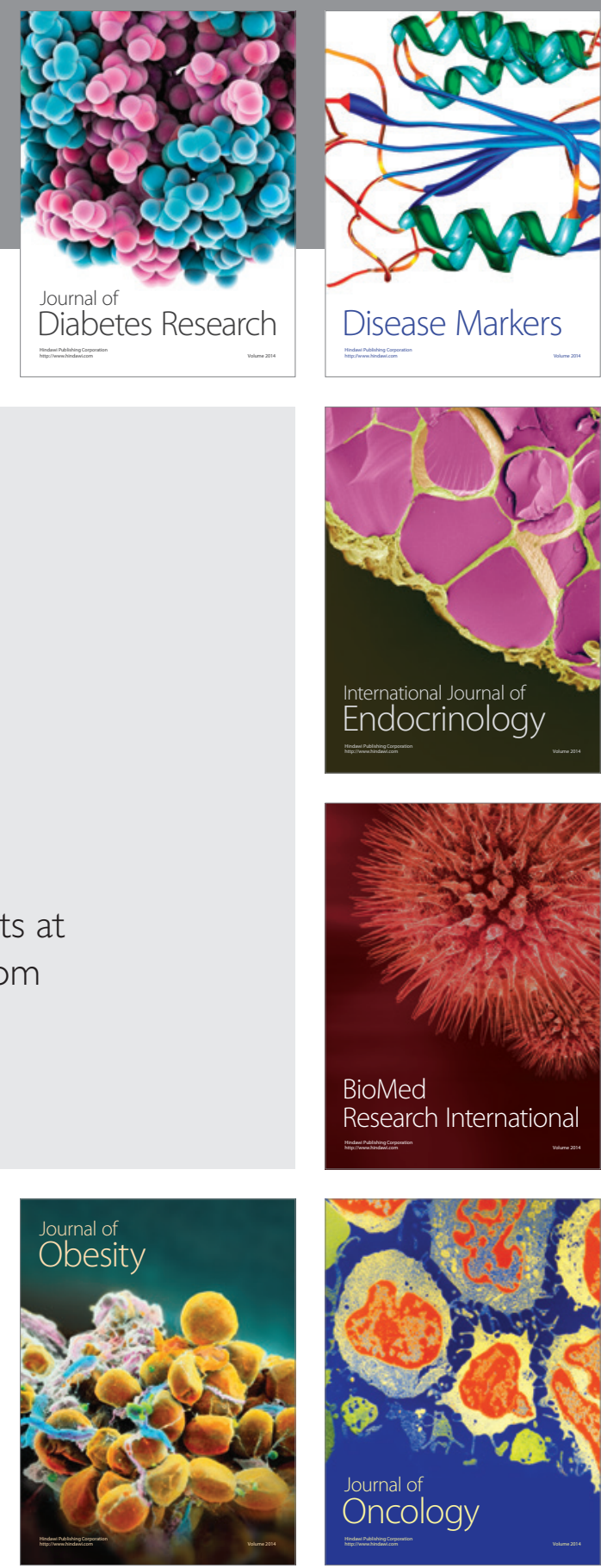

Disease Markers
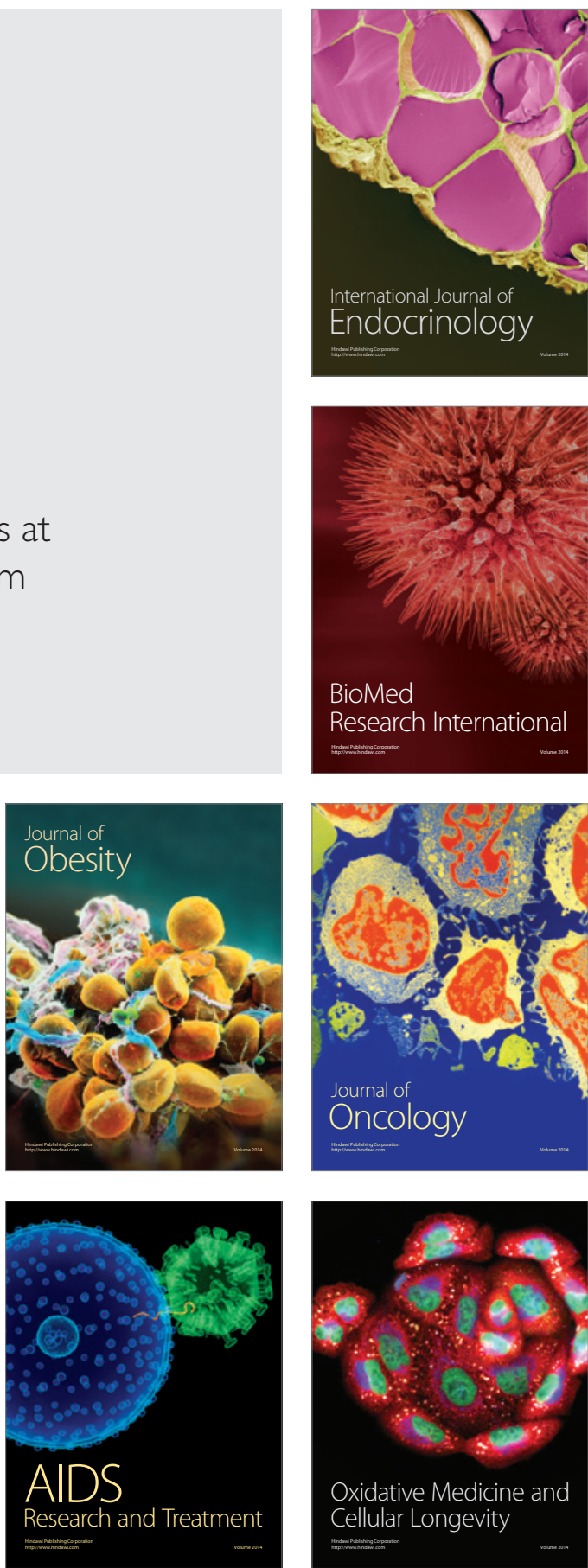